\title{
Pendekatan Praksis-Teologis dalam Fondasi Pendidikan Kristiani
}

\author{
Justice Zeni Zari Panggabean \\ Institut Agama Kristen Negeri Tarutung \\ justicepanggabean@gmail.com
}

\begin{abstract}
This article has some purposes; they are: first, a description of the about theoretical study of a theological practice approach; secondly, explained an implication theological practice approach to the Christian religion education foundation; and thirdly, described a religion studies foundation of Christians in theological practice approach. The method used in this article is an analysis-descriptive of literature available related to the problem that discussed. This research concluded that a practical approach theological in education foundation the Christian religion came into existence from the application of the truth in the life of that can be used with confidence as cornerstones biblical, and search for clues definitive from general principles offered by theology.
\end{abstract}

Article History

Submit:

01 Oktober 2018

Revised:

20 Oktober 2018

Accept:

27 Oktober 2018

Keywords:

Practise Theology approach; Christian religious education foundation

\begin{abstract}
Abstrak
Tulisan ini memiliki beberapa tujuan, yaitu: pertama, mendeskripsikan kajian teoretis pendekatan praksis teologis; kedua, menjelaskan implikasi praksis-teologis fondasi pendidikan Agama Kristen. Metode yang digunakan adalah analisis deskriptif terhadap kajian pustaka yang berkaitan dengan tema fondasi Pendidikan Agama Kristen. Penelitian ini memiliki kesimpulan bahwa pendekatan praktis teologis dalam fondasi pendidikan agama Kristen terwujud dari penerapan kebenaran ke dalam kehidupan yang bisa digunakan dengan percaya diri sebagai fondasi Alkitabiah, dan mencari petunjuk definitif dari prinsip-prinsip umum yang ditawarkan oleh teologi.
\end{abstract}

\section{Kata kunci:}

praksis teologi; Fondasi Pendidikan Agama Kristen

\section{Pendahuluan}

Teologi Kristen, dalam arti yang paling teknis dan sederhana, adalah bidang ilmu yang mengartikulasikan pengertian makna Allah dalam kehidupan kita berdasarkan penyelidikan yang sistematis dan teliti, baik terhadap tradisi iman Kristen maupun pengalaman hidup dari orang-orang. Para teolog memiliki kecakapan-kecakapan dan pendidikan yang khusus untuk melaksanakan riset sehingga memberi mereka kompetensi untuk menafsirkan, menjelaskan 
dan mengembangkan makna dari tradisi iman kita karena makna dari tradisi iman kita saling berhubungan dengan situasi manusia disetiap waktu dalam sejarah. ${ }^{1}$

Dari pendekatan praksis teologi dalam perspektif pendidikan agama Kristen memiliki dua arah yang mempertahankan "theoria" dan "praksis" dalam kesatuan dialektis. Pertamapertama, pendidikan dalam tradisi iman Ktisten dan atas nama (yakni "dari” dalam) komunitas Kristen harus diinformasikan oleh pemahaman mutakhir yang terbaik yang orang Kristen miliki dari tradisi mereka. Pendidikan agama Kristen yang tidak diinformasikan teologi adalah sebuah penyimpangan yang sangat mungkin menggagalkan tujuan pendidikan agama Kristen yang diharapkan. Bahwa pendekatan berbagi praksis juga harus diinformasikan oleh teologi Kristen yang dapat dipercaya. Program-program pelatihan guru bagi para pendidik agama Kristen harus memperhatikan pembentukan teologis dan perkembangan pendidikan.

Di sisi lain, meskipun pendidikan agama Kristen harus diinformasikan oleh pengetahuan teologi yang dapat dipercaya, para pakar harus juga diinformasikan oleh iman yang hidup dari komunitas Kristen. Pada saat para pakar memberi perhatian pada sumbersumber tradisi, mereka harus juga diinformasikan oleh pengalaman historis masa kini dari komunitas iman yang direfleksikan dari sudut tradisi itu. Dalam arti ini, teologi harus timbul dari dan diinformasikan oleh refleksi atas tindakan Kristen masa kini yang terjadi dalam kelompok berbagi praksis. Sesungguhnya, ketika sekelompok orang merefleksikan pengalaman historis masa kini secara kritis dari sudut Cerita/Visi Kristen dikatakan sedang "berteologi". Teologi harus timbul dari praksis Kristen sebanyak teologi harus menginformasikan praksis Kristen yang selanjutnya. Kita harus memandang teologi dan pendidikan agama Kristen sebagai mitra yang setara dalam panggilan komunitas Kristen untuk menghidupkan iman di mana komunitas Kristen meminta untuk percaya dan membentuk orang-orang di dalamnya. Tanpa hubungan kerja sama timbal balik kedua usaha tersebut sangat miskin. ${ }^{2}$

Fenomena yang ada memperlihatkan bahwa sebagian pendekatan praksis teologi hanya menekankan kompetensi untuk menafsirkan, menjelaskan pembebasan yang kontekstual tanpa memperhatikan penerapan praktis teologis terhadap pendidikan agama Kristen. Richard P.Mc Brien mengatakan bahwa Teologi yang baik sangat penting bagi pendidikan agama yang baik; dan teori serta praktik pendidikan yang baik sangat penting untuk mempelajari dan mengkomunikasikan teologi yang baik. Akibatnya, tidak ada

\footnotetext{
${ }^{1}$ Thomas.H.Groome, Christian Religious Education, Jakarta: BPK Gunung Mulia, 2014, 337.

${ }^{2}$ Ibid., 27
} 
hubungan yang lain yang dapat diterima antara pendidikan agama dan teologi kecuali hubungan saling menghargai dan kerja sama. ${ }^{3}$

Fenomena yang ada memperlihatkan bahwa mengomunikasikan teologi melalui studi kritis Alkitab selalu mulai dengan mempertanyakan segala sesuatu yang sudah diterima umum, khususnya Gereja dan orang Kristen; bahkan mempertanyakan ulang yang sudah mendarah daging. Hal itu terjadi juga karena kesimpulan-kesimpulan yang dihasilkan oleh studi kritis tersebut sering kurang dapat diterima oleh banyak orang. ${ }^{4}$ Untuk itu diperlukan orang-orang yang mampu menerapkan teologi secara praktis dalam pendidikan agama Kristen, karena Pendidikan Agama Kristen bersumber dari Alkitab.

Dasar teologis pendidikan agama Kristen adalah alasan alkitabiah tentang pentingnya pendidikan agama Kristen yang terdiri dari tugas, proses dan tujuan pendidikan agama Kristen. Dasar teologis terdapat dalam Amanat Agung Tuhan Yesus (Mat. 28:19-20). Dengan memperhatikan perintah-perintah Tuhan Yesus Kristus kepada para murid-Nya sebelum kenaikan-Nya ke surga, yaitu "pergilah", "jadikanlah", "semua bangsa murid-Ku", "baptislah", dan "ajarlah". Dengan kata lain ada tiga hal yang harus dilakukan para murid Kristus, yaitu memberitakan injil, membaptis dan mengajar. Pendidikan Agama Kristen berhubungan dengan mengajar.

Sasaran menginjil, membaptis dan mengajar adalah menjadikan mereka sebagai murid Kristus. Proses Pendidikan Agama Kristen adalah memuridkan (2 Tim. 2:2). Ayat tersebut menekankan bahwa tujuan mengajar adalah agar dapat mengajar kepada orang lain. Inilah yang dimaksud dengan pemuridan. ${ }^{5}$ Para pendidik Kristen terpanggil untuk tetap setia di dalam teori dan praktik pendidikan Kristen terpanggil untuk kembali mengevaluasi pikiran dan praktik yang berkaitan dengan pendidikan Kristen. Alkitab adalah sebuah instrument kritis yang mampu membedakan dan menilai para pendidik, peserta didik, serta proses pendidikan. ${ }^{6}$

Berkenaan dengan dasar teologis yang dinyatakan dalam Alkitab yang disebut firman Allah. Hal ini mengenai seluruh isi Alkitab, pendidikan agama bersifat relevan, yang artinya mempunyai relasi atau hubungan langsung dengan orang yang menjadi objek pendidikan itu. ${ }^{7}$ Saat menekankan otoritas esensial dari Kitab Suci sebagai orang Kristen Injili telah diarahkan untuk memegang teguh kepada sumber Alkitab di dalam seluruh area iman dan kehidupan

\footnotetext{
${ }^{3}$ McBrien, Basic Questions for Chirstian Educators, Jakarta: BPK Gunung Mulia, 2014, 30-31.

${ }^{4}$ Wismoady Wahono, Di Sini Kutemukan, Jakarta: BPK.Gunung Mulia, 2009, 23

${ }^{5}$ Paulus Lilik Kristianto, Prinsip \& Praktek Pendidikan Agama Kristen, Yogyakarta: ANDI, 2006, 5-6

${ }^{6}$ Robert W.Pazmino, Fondasi Pendidikan Kristen, Jakarta: BPK.Gunung Mulia, 2012, 3

${ }^{7}$ Homrighausen \& Enklaar, Pendidikan Agama Kristen, Jakarta: BPK.Gunung Mulia, 2013, 68
} 
mereka dengan serius. Karena itu, berkaitan dengan pendidikan, orang Injili berpaling kepada Kitab Suci dan berbagai prinsip teologi Alkitabiah didalam mempertimbangkan berbagai prinsip, yang menjadi dasar dalam usaha pembangunan teori dan praktik pendidikan.

Umumnya, kelompok Injili cenderung menekankan pendekatan teologi dalam pendidikan dan bukannya pada pendekatan lain yang menyoroti ilmu sosial. Karena itulah orang Injili lebih menyukai istilah pendidikan Kristen, daripada pendidikan agama, untuk menegaskan penekanan pada perbedaan aspek-aspek kekristenan dalam teologi yang memandu pola pikir dan praktik pendidikan mereka yang menekankan eksplorasi berbagai prinsip-prinsip teologi dan menekankan hubungan. ${ }^{8}$

Berdasarkan latar belakang masalah tersebut diatas yang diuraikan berdasarkan Pendekatan Praksis Teologi dalam Persepektif Pendidikan Kristen. Maka penulis membatasi dengan pertanyaan yakni: Pertama, apakah pendekatan praksis teologis itu? Kedua, apakah implikasi pendekatan praksis teologis terhadap fondasi pendidikan Agama Kristen? Ketiga, bagaimanakah fondasi pendidikan Agama Kristen dalam pendekatan praksis teologis?

Dalam penulisan karya ilmiah ini menggunakan metode penelitian pustaka yang berkaitan dengan permasalahan yang ditulis. Data primer yang digunakan adalah buku-buku yang berkaitan langsung dengan objek penelitian, data dari internet, jurnal dan karangan yang tidak diterbitkan serta beberapa sumber yang menyangkut topik yang diteliti.

\section{Metodologi}

Metodologi yang digunakan dalam artikel ini adalah deskriptif dengan pendekatan kualitatif pada literatur (pustaka). Penulis menggunakan padangan teori para ahli tentang Pendidikan Kristiani dan berbagai pendekatannya, termasuk di dalamnya pendekatan praksis. Pendekatan praksis diusulkan sebagai pendekatan yang dapat digunakan dalam membuat fondasi teori Pendidikan Agama Kristen. Penulis menguraikan berbagai teori dan kemungkinan untuk mengaplikasikan pendekatan tersebut sebagai fondasi Pendidikan Agama Kristen.

\section{Pembahasan}

Dalam penulisan karya ilmiah ini memiliki tujuan penulisan yakni :Pertama, Untuk mengetahui tentang kajian teoritis pendekatan praksis teologis. Kedua, Untuk memaparkan implikasi pendekatan praksis teologis terhadap pendidikan agama Kristen.Ketiga, Untuk mengetahui kajian fondasi pendidikan agama Kristen dalam pendekatan praksis teologis.

\footnotetext{
${ }^{8}$ Robert W.Pazmino, 71
} 
Kata "teologi" berasal dari bahasa Yunani koine, tetapi memperoleh makna dalam Latinnya oleh para penulis Kristen. Teologi adalah ilmu yang membahas ajaran mengenai Allah dan membahas keseluruhan ajaran dan praktik Kristen. Teologi adalah pengetahuan adikodrati yang metodis, sistematis dan koheren tetang apa yang diimani sebagai wahyu Allah atau berkaitan dengan wahyu tersebut. ${ }^{9}$ Berdasarkan defenisi tersebut teologi merupakan ajaran yang meliputi dan berhubungan dengan Tuhan.

Praksis adalah cara mengetahui yang berdasarkan hubungan, pengalaman dan bersifat reflektif, dimana dengan refleksi kritis asas pengalaman yang hidup, orang-orang menemukan dan mengungkapkan cerita dan visi miliknya sendiri, dan dalam konteks pendidikan Kristen. Dengan demikian, praksis itu menggabungkan pengetahuan yang muncul dari pengalaman hidup masa kini dengan apa yang diketahui oleh orang-orang Kristen. Selanjutnya pengetahuan yang timbul dari perjumpaan dengan cerita dan visi Kristen yang berdasarkan pengalaman/bersifat reflektif menuju iman Kristen yang hidup oleh anugerah Allah. ${ }^{10}$ Dalam sejarah kekristenan konteks teologi membentuk teori pendidikan.

Pendekatan praktis teologi dalam pendidikan agama kristen berdampak pada respons manusiawi yang memahami sikap pluralisme antara satu dengan yang lainya sehingga bersikap terbuka terhadap komitmen-komitmen untuk memberi dan menerima penemuan, pemahaman, dan transformasi bersama. ${ }^{11}$ Maka diperlukan pendekatan praksis teologis untuk memilih dan menolong para pendidik melaksanakan dan merencanakan pendidikan agama Kristen dengan mencerminkan realitas dari kebenaran Alkitabiah. ${ }^{12}$ Schaeffer menyatakan bahwa ada alasanalasan teologis penting dibalik perlunya mempunyai Roh yang lebih Alkitabiah bagi mereka yang melayani dalam nama Yesus Kristus. Setiap pendidik Kristen mempunyai satu teologi. Pada titik tertentu teologi seseorang harus di demonstrasikan dalam hubungan antara dirinya dengan Tuhan, dan antara dirinya dengan orang lain. Dalam hubunganlah kita dapat memeriksa nilai, kepercayaan dan perilaku yang mengalir dari keyakinan teologis kita. Karena ada ruang untuk perbedaan pendapat dalam masalah-masalah teologis, di dalam gereja harus ada tingkat toleransi yang memadai untuk cara seseorang memperlihatkan keyakinan teologis. ${ }^{13}$

\section{Pembahasan}

Efek penentuan teologi yang berkaitan dengan pelayanan sering diperlihatkan dalam sebuah alat hierarkis yang disebut "ensiklopedia teologis" sebuah perwakilan visual tentang

\footnotetext{
${ }^{9}$ Nico Syukur Dister, Pengantar Teologi, Yogyakarta: Kanisius, 2009, 17

${ }^{10}$ Sara Little, Theology and Religious Education, Nashville: Abingdon, 1983, 33

${ }^{11}$ Hope S.Antone, Pendekatan Kristiani Kontekstual, Jakarta: BPK.Gunung Mulia, 2012, 39

${ }^{12}$ Antone, Pendekatan Kristiani Kontekstual, 42

${ }^{13}$ Michael J.Anthony, Foundations of Ministry, Bandung: Gandum Mas, 2012, 23-25
} 
kesinambungan tafsir Alkitab sampai dengan aplikasi kebenaran. Walaupun presentasi ensiklopedik kemajuan dari tulisan kepada hidup mungkin rumit, biasanya skema umumnya dapat dikurangi menjadi tiga komponen dasar yaitu sejarah gereja, dogmatik dan kitab suci. ${ }^{14}$ Pada gilirannya, teologi adalah untuk menginformasikan praktik kehidupan Kristen.

Kekuatan ensiklopedia terletak dalam hal ensiklopedia memperlihatkan bahwa praktik kehidupan Kristen (sejarah gereja) dapat dipimpin oleh pemikiran saksama (dogmatika) yang di dasarkan pada wewenang Firman Tuhan (Kitab Suci). Tetapi, kemajuan yang diperlihatkan dalam ensiklopedia juga mencerminkan sebuah kelemahan dalam banyak dari teori-teori Pendidikan Kristen yang ada. Ensiklopedia menghilangkan pengaruh langsung dari Firman Tuhan pada kehidupan Kristen dengan disiplin teologis sekunder. Penjelasan teologis yang didasarkan atas studi teliti tentang tulisan dalam Kitab Suci sangat membantu. Teologi sangat penting bagi praktik kehidupan Kristen. Dengan cara historis langsung, pendekatan ensiklopedik menyebabkan potensi pemisahan komponen-komponen dari pemikiran Kristen yang seharusnya tetap bersatu. Hal ini menginsprirasi terjadinya "pembagian" dan "departemen" dalam pendidikan teologis yang antara satu dengan lainnya terlalu sering bersaing untuk menonjolkan dirinya masing-masing. Hal ini menggambarkan Pendidikan Kristen sebagai tambahan ketiga pada studi Alkitabiah dan studi teologi yang sebenarnya. ${ }^{15}$

Prinsip-prinsip pengorganisasian yang terbaik yang berkatian dengan aspek-aspek kognitif, afektif, dan perilaku yang terbuka membawa pada filosofis berbeda. Gangel dan Benson menyatakan bahwa secara umum menemukan kebenaran dari sistem dan situasi yang dialami oleh Paulus karena membentuk sebuah "sistem" yang tidak menyenangkan bagi lawanlawannya dari pola duniawi manapun karena kepedulian utamanya yang bersifat Alkitabiah. ${ }^{16}$

Perkembangan Pendidikan Kristen yang interaktif ini menghasilkan beberapa keuntungan. Pernyataan bahwa Kristus dan implikasi pendidikan harus diberikan penekanan yang jelas. Penerimaan yang hampir total dari sudut pandang perkembangan struktural dan luasnya akomodasi konseptual terhadap pendekatan ini dalam Pendidikan Kristen memberikan jembatan yang sesuai untuk bergerak dengan cepat dari "dunia dan pandangan hidup" Kristen secara umum kepada perencanaan dan rancangan kurikulum pendidikan. Pematangan kemampuan kognitif dan moral secara alami yang merupakan pendirian utama develop mentalism, secara luas diterima sebagai dasar yang memadai untuk metodologi dalam

\footnotetext{
${ }^{14}$ Edward Farley, Theologia:Fragmentatiuon and Unity of Theological Education, Philadelphia: Fortress Press, 1993, 30

${ }^{15}$ Anthony, Foundations of Ministry, 28

${ }^{16}$ Kenneth O.Gangel dan Warren S.Benson, Chiristian Education: ITS Story and Philosophy, Chicago: Moody Press, 1993, 339
} 
pendidikan Kristen. Para pendidik Kristen mengadopsi pendekatan strukturalis sebagai fondasi untuk praksis perkembangan moral dan pemeliharaan rohani Kristen. ${ }^{17}$

Paulus menyediakan sebuah konstruksi (iman, pengharapan dan kasih) untuk penerapan kebenaran ke dalam kehidupan yang bisa digunakan dengan percaya diri sebagai fondasi Alkitabiah untuk Pendidikan Kristen di semua usia. Untuk menjadi pedoman yang berwenang bagi pelayanan pendidikan, iman, pengharapan dan kasih harus berhubungan dengan petunjuk perilaku tertentu yang ditemukan dalam firman Tuhan dalam porsi yang relevan. Pendekatan yang dilakukan mencari petunjuk definitive dari prinsip-prinsip umum yang ditawarkan oleh teologi. Tetapi, sebagaimana tercatat sebelumnya, terminologi teologi tidak dengan mudah dapat diterjemahkan ke dalam kategori-kategori yang membentuk struktur pemikiran pendidikan. Dengan tujuan menerima petunjuk yang berwenang dari Kitab Suci, tafsir Alkitab harus dicapai melalui pendekatan alami kepada pembaca Kitab Suci. Sebuah metoda historisgramatik dari tafsir Alkitab digunakan untuk menentukan arti ayat-ayat Alkitab dengan analisis penggunaan kata dalam konteks tertentu. Baik keadaan historis maupun struktur gramatik dari ayat mana pun harus dianalisis dengan seksama. Penyatuan konteks dan isi dari suatu ayat menghasilkan tafsir.

Teologi yang didasarkan atas penafsiran yang akurat dari Kitab Suci adalah bantuan yang berharga terhadap pemikian Kristen dan merupakan isi dari banyak instruksi dalam Pendidikan Kristen. Tetapi, teologi bukanlah akhirnya. Demikian juga, diperlukan interaksi dengan penelitian dan teori ilmu perilaku. Ini memberikan wawasan berharga dan mendorong pemikiran kreatif. Dalam Pendidikan Kristen, konstruksi pengetahuan, perspektif dan perilaku yang jelas dan penting ini harus dipimpin oleh kesetiaan pada penafsiran historis-gramatik dari Kitab Suci. Apalagi dalam konteks Indonesia yang majemuk sehubungan dengan kontekstual Erman S. Saragih ${ }^{18}$ mengemukakan bahwa kebhinekaan sebagai realita yang harus dirawat, dijunjung tinggi dan dihormati dalam berbagai aspek hidup melebihi agama. Maka teologi dan hermeneutika harus mempertimbangkan konteks dimana pendidikan Kristen diajarkan. Pertimbangan konteks ajaran yang benar akan menghasilkan iman, pengharapan, dan kasih dalam perkembangan fondasi Alkitabiah untuk pendidikan Kristen.

Sara Little memberikan beberapa kemungkinan hubungan antara teologi dan pendidikan Kristen, yaitu:

a) Teologi adalah konten yang harus diajarkan dalam Pendidikan Kristen

\footnotetext{
${ }^{17}$ Richards, Theolgy of Christian Education, Grand Rapids: Publishing house, 1975,74-76

${ }^{18}$ Saragih, E. (2018). Analisis dan Makna Teologi Ketuhanan Yang Maha Esa dalam Konteks Pluralisme Agama di Indonesia. Jurnal Teologi Cultivation, 2(1), 290-303. Retrieved from http://jurnal.stakpntarutung.ac.id/index.php/Jurnal-Teologi-Cultivation/article/view/44
} 
b) Teologi adalah referensi untuk apa yang harus diajarkan serta untuk metodologi dan berfungsi sebagai norma untuk menganalisis karya-karya kritis dan mengevaluasi semua pendidikan Kristen

c) Teologi tidak relevan dengan tugas pendidikan Kristen; karena pendidikan Kristen sifatnya Otonom

d) "Melakukan teologi" atau teologisasi pendidikan Kristen dalam artian memampukan seseorang untuk merefleksikan pengalaman dan perspektif mereka saat ini di dalam terang iman dan penyataan Kristen

e) Teologi dan pendidikan Kristen adalah dua disiplin ilmu yang berbeda, yang terikat secara mutual dan saling bekerja sama untuk kemajuan kerajaan Allah ${ }^{19}$

Teologi bisa dipandang baik sebagai konten maupun norma. Namun, cara penyampaiannya tidak harus dipaksakan atau dikomunikasikan dengan cara otoriter, akan tetapi bisa dilakukan adanya kepekaan terhadap orang yang bersangkutan dan kebutuhannya. Berdasarkan hal tersebut maka sama seperti pendidikan Kristen mampu berkontribusi pada tugas-tugas teologi, teologi juga bisa berkontribusi pada pendidikan Kristen.

Teologi bisa memberitahu apakah praktik pendidikan Kristen yang dilakukan sudah sesuai dengan Alkitab dengan mengajukan pertanyaan-pertanyaan yang berhubungan dengan kekonsistenan terhadap nilai-nilai Alkitab.

\section{Pembahasan}

Proses sosialisasi Pendidikan Agama Kristen di kalangan keluarga Yahudi dalam Perjanjian Lama dicerminkan dalam pengertian 'didache'. Didache dalam Perjanjian Lama, merupakan inti dari pendidikan Yahudi, yang dasarnya dimulai dalam keluarga. Didache sendiri dapat diartikan sebagai jalan pengajaran atau jalan hidup, dalam hal ini dimaksudkan tidak hanya sebagai tindakan tetapi isi dari pengajaran itu. Dalam Ulangan 6:4-6, yang dikenal sebagai syema yisrael, semacam kalimat syahadat yang harus diajarkan bapak Yahudi kepada seisi rumahnya, dan diulang-ulang oleh setiap orang Yahudi untuk mengingatkan mereka akan Tuhan Allah orang Israel dan perbuatan-perbuatan-Nya yang besar. Dalam didache ini berpusat pada diri dan pekerjaan Yesus. Sejak dari permulaan Injil, Yesus digambarkan sebagai guru, yang membuat para imam dan ahli taurat tercengang oleh ajaran-Nya (didache). ${ }^{20}$

\section{Penyataan Allah dan Hikmat di dalam Alkitab}

Melalui Alkitab kita selayaknya belajar bagaimana Allah pencipta dunia dengan tandatanda yang nyata dibedakan dari seluruh kelompok berhala di dunia. Allah dinyatakan kepada kita di dalam Alkitab sebagai Pembuat dunia, dan kepada kita ditunjukkan pula apa yang harus kita ketahui tentang Dia, supaya kita tidak tersesat ke sana ke mari dalam usaha mencari salah

\footnotetext{
${ }^{19}$ Richards, Theolgy of Christian Education, 97

${ }^{20}$ N.K.Atmadja Hadinoto, Dialog dan Edukasi (Jakarta: BPK.Gunung Mulia, 1999), 212-214
} 
satu ilah yang tidak pasti. ${ }^{21}$ Sesudah itu menyusul para gembala dan pengajar yang kapanpun tak bisa tidak ada di dalam Gereja. Perbedaan antara kedua jabatan ini adalah: pengajar tidak memegang pimpinan dalam hal disiplin Gereja ataupun pelayanan sakramen, atau dalam hal peringatan dan teguran, tetapi hanya dalam hal tafsiran Alkitab, supaya ajaran yang murni dan sejati terpelihara di antara orang-orang percaya. Akan tetapi, jabatan gembala mencakup semua itu. $^{22}$

Hikmat yang Alkitabiah itu bersifat religius dan praksis. Hikmat seperti itu muncul dari takut akan Tuhan (Ayb.28:28; Mzm.111:10; Ams.1:79:10), kemudian bertumbuh sampai ke semua aspek kehidupan. Hikmat memberikan ide-ide yang mendalam yang diperoleh dari pengetahuan tentang jalan-jalan Allah dan perlu diterapkannya dalam kehidupan sehari-hari. ${ }^{23}$

Implikasi pendidikan Kristen dalam Perjanjian Lama, yang pertama adalah Allah memberikan hikmat dan manusia bergantung pada anugerah-Nya untuk bisa memahami hikmat. ${ }^{24}$ Oleh karena itu, hikmat yang terpisah atau tidak konsisten dengan kebenaran penyataan Allah. Pendidikan pada dasarnya harus berpusat kepada Allah, dengan memandang Allah sebagai sumber. Para pendidik dipanggil untuk mengintegrasikan semua bidang pengetahuan dengan penyataan Allah.Implikasi kedua adalah pendidikan harus mempunyai dampak terhadap hidup orang dan seharusnya dapat memampukan mereka untuk menangkap konsekuensi praktis dari kebenaran yang dipelajari atau diteliti dengan seksama. Oleh karena itu, imbauan yang bernuansa sangat teoritis dan akademik yang menyentuh tataran rasio, namun terpisah dari perasaan dan tindakan, tidaklah dapat dikatakan bahwa imbauan tersebut selaras dengan tradisi Alkitab.

Pertanyaan-pertanyaan tentang karakter, etika, dan gaya hidup, patut diajukan dalam kerangka berpikir tentang bagaimana kebenaran dan komitmen itu dikaitkan dengan seluruh area kehidupan. Untuk itu, dibutuhkan perspektif tentang pendidikan yang holistik dan terintegrasi yang akan memengaruhi kepala, hati, dan tangan para pendidik dan peserta didik. ${ }^{25}$ Implikasi ketiga bagi pendidikan adalah bahwa mereka yang berstatus pendidik harus dievaluasi untuk melihat sejauh mana mereka telah mennjukkan kepemilikan akan karunia hikmat yang dari Allah.

\footnotetext{
${ }^{21}$ Yohanes Calvin, Institutio (Pengajaran Agama Kristen), Jakarta:BPK Gunung Mulia, 2013, 22

${ }^{22}$ Ibid., 243

${ }^{23}$ David H.Hubbard, Hikmat (dalam The New Bible Dictionary), Grand Rapids:Eerdmans, 1962, 1333

${ }^{24}$ Harls Evan Rianto Siahaan, "Hikmat Sebagai Implikasi Pendidikan Kristiani Dalam Keluarga: Refleksi 1 Raja-Raja 3:1-15,” DUNAMIS (Jurnal Teologi dan Pendidikan Kristiani) Vol 1, no. 1 (2016): 15-30, www.sttintheos.ac.id/e-journal/index.php/dunamis.

${ }^{25}$ Bimo Setyo Utomo, “(R)Evolusi Guru Pendidikan Agama Kristen Dalam Mentransformasi Kehidupan Siswa," DUNAMIS (Jurnal Teologi dan Pendidikan Kristiani) 1, no. 2 (2017): 102-116, http://www.sttintheos.ac.id/e-journal/index.php/dunamis/article/view/111/100.
} 
Pada akhirnya para pendidik bertanggung jawab kepada Allah atas penggunaan karunia yang mereka miliki dan juga bertanggung jawab kepada para peserta didik dalam mmembagikan hasil kajian mereka. Pendekatan pendidikan yang secara eksklusif menekankan pada pembelajaran yang diarahkan kepada siswa mungkin tidak cukup memberikan peluang bagi pendidik untuk membagikan, mengkontekstualisasikan norma-norma yang menunjukkan bagaimana seharusnya orang menjalani hidup ini. ${ }^{26}$

Melengkapi pendidikan dalam Perjanjian Baru mencakup tiga basis, yaitu basis pertama bagi pemberitaan Injil yang menekankan pentingnya kerygma secara eksplisit dan aktif, maka basis ini juga melambangkan pendidikan tentang pemberitaan Injil. Pendidikan tentang pemberitan Injil mengacu pada proses belajar-mengajar yang lebih bersifat reseptif dan implisif, yaitu pengajaran yang terjadi melalui kesaksian iman Kristen lewat perkataan dan perbuatan. basis kedua melambangkan pendidikan bagi komunitas persekutuan dengan Allah dan orang Kristen lainnya. Pendidikan ini mencakup proses pelatihan, pengajaran, dan pemeliharaan, yang memampukan seseorang untuk bertumbuh dan dewasa dalam iman.

Firman Tuhan juga menunjukkan secara eksplisit bahwa pendidikan yang harus diberikan orangtua kepada anak-anaknya pada dasarnya harus bersifat religius. ${ }^{27}$ Sebenarnya, penekanannya sangat eksklusif pada pendidikan agama yang tampak seakan-akan dianggap sebagai pendidikan yang utuh. Hal ini dapat dijelaskan berdasarkan kenyataan bahwa Alkitab pada dasarnya berurusan dengan kebutuhan religius dan moral seorang manusia, maka agama pun dianggap sebagai hal yang fundamental, hal yang sangat mendasar dari kehidupan seorang manusia. Oleh sebab itu, pendidikan mana pun tidak akan baik dan memuaskan kalau tidak diwarnai dengan semangat agama.

Marilah kita memperhatikan beberapa bagian yang menegaskan hal ini. Dalam Kejadian 18:19 kita dapat menemukan Allah berkata mengenai Abraham, "Sebab Aku telah memilih dia, supaya diperintahkannya kepada anak-anaknya dan kepada keturunannya supaya tetap hidup menurut jalan yang ditunjukkan Tuhan, dengan melakukan kebenaran dan keadilan, dan supaya Tuhan memenuhi kepada Abraham apa yang dijanjikan-Nya kepadanya". Melalui katakata ini kita diberi tahu alasan mengapa Allah memutuskan untuk memberi Abraham sebuah pengertian mengenai keputusan-Nya untuk menghancurkan kota-kota lembah Yordan.Abraham dipilih oleh Allah untuk menjadi bapa dari sebuah bangsa yang besar dan menjadi berkat bagi semua bangsa di bumi.

\footnotetext{
${ }^{26}$ Robert W.Pazmino, Fondasi Pendidikan Kristen, 34-36

${ }^{27}$ Handreas Hartono, "Membentuk Karakter Kristen Pada Anak Keluarga Kristen," KURIOS (Jurnal Teologi dan Pendidikan Agama Kristen) 2, no. 1 (2014): 62-69, www.sttpb.ac.id/e-journal/index.php/kurios.
} 
Tetapi supaya janji-Nya kepada Abraham dapat dipenuhi dan Tuhan dapat memberikan berkat yang dijanjikan, Abraham harus mengajarkan kepada keturunannya "supaya tetap hidup menurut jalan yang ditunjukkan Tuhan, dengan melakukan kebenaran dan keadilan”. Dan supaya dia dapat menjadi guru yang benar-benar efektif yang mengajarkan bahwa berkat dari Yahweh hanya dapat dinikmati dengan ketaatan, dan ketidaktaatan diganjar maut, maka harus diberitahukan kepadanya bahwa kota-kota lembah Yordan akan dihancurkan karena tuntutan keadilan dan kebenaran.

Kitab Ulangan memperingatkan bangsa Israel untuk selalu rajin mengingatkan anakanak mereka mengenai pekerjaan ajaib Allah yang telah memimpin bangsa itu di masa lalu supaya anak-anak ini melayani Allah dengan kerelaan hati.dan kita mendengar apa yang dapat dianggap sebagai jawaban sukacita dari orang Israel yang benar terhadap semua peringatan ini. $^{28}$

Para pendidik Injili secara sadar memegang penyataan Alkitab dan mengklaim bahwa mereka berada "di bawah firman Allah". Firman Allah yang tertulis adalah Kitab Suci di dalam keutuhannya serta keragaman isinya, dan kaum Injili berusaha mengajarkan seluruh hikmat Allah. Dengan cara ini orang percaya dihubungkan kepada sumber utama atau otoritas untuk membedakan iman Kristen. Sikap ini mengimplikasikan bahwa bukan literalisme yang tanpa pertimbangan, tetapi adalah proses mnghasilkan norma bagi pikiran dan kehidupan melalui proses pemaknaan kebenaran Kitab Suci yang tepat dan apa adanya. Kitab Suci berfungsi sebagai otoritas final dan sebagai filter (penyaring) yang digunakan untuk memeriksa semua kebenaran apakah sesuai dengan konsisten atau tidak dengan dunia dan cara pandang kekristenan. $^{29}$

Teologi secara teknis berada di dalam Pendidikan Agama Kristen, atau dengan kata lain teologia sudah menjadi isi (content) dalam Pendidikan Agama Kristen. Hal tersebut telah terbukti, ketika guru mengajar materi Pendidikan Agama Kristen, maka ajarannya berisi ajaran Alkitab, yang di dalamnya sudah terkandung teologi. Dengan berfungsi sebagai isi (content), proses, metode, dan sebagai norma. Untuk menyampaikan Firman-Nya kepada manusia, Allah telah memilih orang-orang tertentu, dan Roh Kudus mengendalikan apa yang mereka tulis sehingga tulisan yang mereka hasilkan, yaitu Alkitab, merupakan amanat Allah. Dengan demikian, ketepatan dan kesempurnaan Firman itu terjamin. ${ }^{30}$

\footnotetext{
${ }^{28}$ Louis Berkof dan Cornelius Van Til, Dasar Pendidikan Kristen, Surabaya:Momentum Christian Literature, 2013, 44-45

${ }^{29}$ Robert W.Pazmino, Fondasi Pendidikan Kristen, 73

${ }^{30}$ Lawrence O.Richard, Mengajarkan Alkitab secara kreatif, Bandung: Yayasan Kalam Hidup, 1993, 16
} 


\section{Prinsip Teologi Praktis}

Teologi praktis adalah teori teologi yang menghubungkan tradisi iman Kristen dalam praksis masyarakat modern. Teologi praktis memiliki rorientasi yang bersifat empirik. ${ }^{31}$ Van Kessel melihat tugas teologi praktis sebagai "menyusun praksis yang membebaskan, dalam proses melihat (pengamatan, pengalaman dan analisis), menilai (mengevaluasi berdasarkan kriteria), dan bertindak (merencanakan dan merealisasikan proyek-proyek). Semua ini berlangsung lewat gerak timbal balik satu sama lain, menurut teori yang baru mengenai hubungan antar teori dan praksis. Yang sentral disini adalah dua motif yaitu peran subjek yang mengenal dan berfungsinya teori dan praktek secara ideologis dan historis praktis. ${ }^{32}$

Dalam dunia pendidikan dikenal istilah didaktik. Didaktik adalah ilmu mengajar, tetapi bukan asal mengajar. Didaktik adalah ilmu mengajar yang menimbulkan proses belajar. Kata didaktik berasal dari kata Yunani disebut didaskein. Kata didaskein lebih berarti mengajar/belajar untuk bertindak secara jitu. ${ }^{33}$ Dalam proses tersebut guru melakukan pembimbingan dengan harapan naradidik akan memberikan tanggapannya secara aktif atas apa yang sedah ia pelajari. Ketika naradidik memberikan tanggapannya, itulah saat yang sangat penting dalam proses mengajar oleh karena berbagai pertanyaan dan masalah dapat muncul dan memerlukan percakapan, saling membagikan pengalaman sehingga keduanya yaitu guru dan naradidik diperkaya dan menemukan nilai pelajaran yang sedang digumuli. Dalam proses pembimbingan tersebut seorang guru sedang mengajar, artinya: ia punya tugas yang amat penting dalam mengarahkan dan memproses pembimbingan atas apa yang diajarkan. ${ }^{34}$

Sebuah simbol selalu bermakna majemuk sehingga penggunaannya antara pengajar dan pelajar terjadi melalui proses yang rumit. Namun di lain pihak bahasa simbol menjadi hal yang menarik bagi Pendidikan Agama Kristen, sebab pengajar ditantang untuk peka terhadap perbedaan makna sebuah kata antara pengajar dan pelajar, sedangkan pelajar ditantang untuk mengolah sendiri suatu makna bagi suatu kata. Dengan simbol maka kita dileluasakan untuk merasakan takjub serta takzim, dengan imajinasi dan fantasi.Sebab itu, salah satu dasar teologi Pendidikan Agama Kristen adalah teologi simbolisme.

Kita dapat mengetahui banyak tentang perkembangan manusia dan tentang proses belajar-mengajar dari sistem sekular. Walaupun itu sangat membantu namun tidak akan pernah cukup untuk suatu falsafah pendidikan Kristen. Para pendidik Kristen sering berpindah dari

\footnotetext{
${ }^{31}$ Rijinardus dan Sri Agus Patnaningsih, Menguak Fakta Menata Karya Nyata, Jakarta: BPK.Gunung Mulia, 2003, 67

${ }^{32}$ Gerben Heitink dan Ferd leselaars Hartono, Teologi Praktis (Pastoral dalam Era Moderenitas), Yogyakarta: Kanisius, 2005, 94

${ }^{33}$ J.L.Ch.Abineno, Sekitar Katekese Gerejawi-Pedoman Guru, Jakarta: BPK.Gunung Mulia, 1988, 5

${ }^{34}$ Andar Ismail, Ajarlah Mereka Melakukan, Jakarta: BPK.Gunung Mulia, 2006, 90-91
} 
satu mode pendidikan kepada mode yang lain tanpa merenungkan secara mendalam prinsipprinsip teologis yang mendasari kecenderungan itu. Karena landasan alkitabiahnya kurang, para pengajar secara tidak kentara terpengaruh filsafat sekular yang lebih rendah daripada kesadaran teologis. Untuk membaharui pendidikan Kristen kita perlu memikirkan ulang makna pengajaran. Kita terlalu sering menganggap pengajaran sebagai pemberitahuan.Sehingga diperlukan hubungan yang jelas (interaksi) antara pengajaran Alkitab dengan kebutuhan anak didik melalui Firman Allah yang hidup dan penuh kuasa.Mendorong interaksi bermakna dengan memberikan contoh terbaik sebagai implikasi praksis dari materi yang disampaikan. ${ }^{35}$

Alkitab sebagai suatu kesaksian tentang penyataan Allah dan yang ikut serta dalam peristiwa-peristiwa penyataan itu, mempunyai arti yang penting dan unik untuk jemaat Tuhan dan kehidupan manusia pada umumnya. Alkitab berguna bagi manusia karena Alkitab memberi kesaksian tentang apa yang dilakukan Allah dan cara-cara yang dipergunakan Allah untuk menyatakan diri-Nya kepada umat-Nya. ${ }^{36}$

Alkitab adalah kesaksian tentang pernyataaan Allah dalam arti bahwa Alkitab berisi catatan tentang penyataan yang mula-mula di mana jemaat terbentuk, dan karenanya juga jemaat itu masih terus bertahan. Alkitab bukanlah penyataan Allah itu sendiri, melainkan hanya menunjuk kepada penyataan itu.Alkitab adalah catatan tertulis dari penyataan itu. Alkitab adalah catatan tentang sumber sejarah mengenai masyarakat Kristen dan kepercayaan orang Kristen. ${ }^{37}$

\section{Kesimpulan}

Pendekatan praksis teologi diperlukan untuk menjadi fondasi pendidikan agama Kristen. Pendidikan agama Kristen membutuhkan konteks kegiatan pendidikan yang memberikan pendekatan dalam bentuk refleksi (teori) atau metode pendidikan agama Kristen. Istilah "pendekatan" memiliki kemungkinan untuk menunjuk ke arah disposisi utama yang dibawa inisiator ke dalam kegiatan. Sikap utama para pendidik diperlukan untuk membentuk kegiatan pendidikan agama Kristen. Pendekatan praksis ini harus menjadi proses yang terusmenerus diperbaharui dimana teori dijelaskan dalam praksis untuk memberdayakan praksis selanjutnya.

Pendekatan teologis membentuk fondasi pendidikan agama Kristen yang secara eksklusif menekankan pada pembelajaran yang dengan berbagai metode yang Alkitabiah sehingga peserta didik lebih membangkitkan pengetahuan yang bervariasi. Oleh sebab itu,

\footnotetext{
${ }^{35}$ Lois E.Lebar, Education that is Christian (Malang: Gandum Mas, 2006), 32-33

${ }^{36}$ Cully, Dinamika Pendidikan Kristen,98

${ }^{37}$ Butler, Religious Education, 150
} 
para pendidik harus mengetahui, memahami, mengerti dasar-dasar apakah yang menjadi landasan ketika membangun, melakukan, serta mempraktekkan proses pendidikan Kristen yang digunakan sebagai fondasi yang menjawab kebutuhan untuk mengajarkan iman Kristen untuk tetap setia dalam teori dan praktek pendidikan agama Kristen kepada generasi selanjutnya. Dengan terlebih dahulu mengeksplorasi dari pendekatan praksis teologis maka akan mampu mengidentifikasi prinsip-prinsip dan implikasi pendidikan yang bisa dipraktekkan.

Pendekatan teologi dalam Kristen menegaskan penekanan pola pikir praktek pendidikan yang menghasilkan elemen dari otoritas Alkitab yaitu firman Allah, pentingnya pertobatan melalui pemberitaan injil dan melengkapi katekisasi. Fondasi pendidikan agama Kristen akan lebih baik jika pengajaran yang dilakukan memenuhi pertimbangan teologis yang dilakukan secara praksis. Pengalaman iman yang hidup yang diinformasikan oleh tradisi iman Kristen dan pemakaian tradisi yang diinfomasikan oleh pengalaman iman yang hidup dalam konteks pengalaman iman hidup. Hanya dengan demikian cara pendekatan praksis teologis untuk menerapkan metode pengajaran yang direfleksikan dalam pendidikan.

\section{Referensi}

Andar Ismail, Ajarlah Mereka Melakukan, Jakarta: BPK.Gunung Mulia, 2006

David H.Hubbard, Hikmat (dalam The New Bible Dictionary), Grand Rapids:Eerdmans, 1962

Edward Farley, Theologia:Fragmentatiuon and Unity of Theological Education, Philadelphia: Fortress Press, 1993

Saragih, Erman S. (2018). Analisis dan Makna Teologi Ketuhanan Yang Maha Esa dalam Konteks Pluralisme Agama Di Indonesia. Jurnal Teologi Cultivation, 2 (1), 290-303.

Gerben Heitink dan Ferd leselaars Hartono, Teologi Praktis (Pastoral dalam Era Moderenitas), Yogyakarta: Kanisius, 2005

Hartono, Handreas. "Membentuk Karakter Kristen Pada Anak Keluarga Kristen.” KURIOS (Jurnal Teologi dan Pendidikan Agama Kristen) 2, no. 1 (2014): 62-69. www.sttpb.ac.id/e-journal/index.php/kurios.

Homrighausen \& Enklaar, Pendidikan Agama Kristen, Jakarta: BPK.Gunung Mulia, 2013 Hope S.Antone, Pendekatan Kristiani Kontekstual, Jakarta: BPK.Gunung Mulia, 2012 Iris Cully, Dinamika Pendidikan Kristen, Jakarta: BPK.Gunung Mulia, 2009 James Donal Butler, Religious Education, Harper, 2007

J.L.Ch.Abineno, Sekitar Katekese Gerejawi-Pedoman Guru, Jakarta: BPK.Gunung Mulia, 1988

Kenneth O.Gangel dan Warren S.Benson, Chiristian Education: ITS Story and Philosophy, Chicago: Moody Press, 1993

Lawrence O.Richard, Mengajarkan Alkitab secara kreatif, Bandung: Yayasan Kalam Hidup, 1993

Lois E.Lebar, Education that is Christian, Malang: Gandum Mas, 2006

Louis Berkof dan Cornelius Van Til, Dasar Pendidikan Kristen,Surabaya: Momentum Christian Literature, 2013

McBrien, Basic Questions for Chirstian Educators,Jakarta: BPK Gunung Mulia, 2014 
Mizhael J.Anthony, Foundations of Ministry, Bandung: Gandum Mas, 2012

N.K.Atmadja Hadinoto, Dialog dan Edukasi, Jakarta: BPK.Gunung Mulia, 1999

Nico Syukur Dister, Pengantar Teologi, Yogyakarta: Kanisius, 2009

Paulus Lilik Kristianto, Prinsip \& Praktek Pendidikan Agama Kristen, Yogyakarta: ANDI, 2006

Richards, Theolgy of Christian Education, Grand Rapids: Publishing house, 1975

Rijinardus dan Sri Agus Patnaningsih, Menguak Fakta Menata Karya Nyata, Jakarta:

BPK.Gunung Mulia, 2003

Robert W.Pazmino, Robert W.Pazmino, Fondasi Pendidikan Kristen, Jakarta: BPK.Gunung Mulia, 2012

Siahaan, Harls Evan Rianto. "Hikmat Sebagai Implikasi Pendidikan Kristiani Dalam Keluarga: Refleksi 1 Raja-Raja 3:1-15.” DUNAMIS (Jurnal Teologi dan Pendidikan Kristiani) Vol 1, no. 1 (2016): 15-30. www.sttintheos.ac.id/ejournal/index.php/dunamis.

Thomas.H.Groome,Christian Religious Education, Jakarta: BPK Gunung Mulia, 2014

Utomo, Bimo Setyo. "(R)Evolusi Guru Pendidikan Agama Kristen Dalam Mentransformasi Kehidupan Siswa.” DUNAMIS (Jurnal Teologi dan Pendidikan Kristiani) 1, no. 2 (2017): 102-116. http://www.sttintheos.ac.id/ejournal/index.php/dunamis/article/view/111/100Sara Little, Theology and Religious Education, Nashville: Abingdon, 1983

Wismoady Wahono, Di Sini Kutemukan, Jakarta: BPK.Gunung Mulia, 2009

Yohanes Calvin, Institutio (Pengajaran Agama Kristen), Jakarta:BPK Gunung Mulia, 2013 